\title{
Molecular and Cellular Effects of Hydrogen Peroxide on Human Lung Cancer Cells: Potential Therapeutic Implications
}

\author{
Gabriela Vilema-Enríquez, ${ }^{1,2,3}$ Aurora Arroyo, ${ }^{4}$ Marcelo Grijalva, ${ }^{1,2}$ \\ Ricardo Israel Amador-Zafra, ${ }^{5}$ and Javier Camacho ${ }^{1,4}$ \\ ${ }^{1}$ Departamento de Ciencias de la Vida, Universidad de las Fuerzas Armadas (ESPE), Avenida General Rumiñahui, \\ S/N, P.O. Box 171-5-231B, Sangolquí, Ecuador \\ ${ }^{2}$ Centro de Nanociencia y Nanotecnología, Universidad de las Fuerzas Armadas (ESPE), Avenida General Rumiñahui, \\ S/N, P.O. Box 171-5-231B, Sangolquí, Ecuador \\ ${ }^{3}$ Department of Physiology, Anatomy and Genetics, University of Oxford, Le Gros Clark Building, South Parks Road, \\ Oxford OX1 3QX, UK \\ ${ }^{4}$ Department of Pharmacology, Centro de Investigación y de Estudios Avanzados del Instituto Politécnico Nacional, \\ Avenida Instituto Politécnico Nacional 2508, 07360 Mexico City, DF, Mexico \\ ${ }^{5}$ Department of Genetics and Molecular Biology, Centro de Investigación y de Estudios Avanzados del \\ Instituto Politécnico Nacional, Avenida Instituto Politécnico Nacional 2508, 07360 Mexico City, DF, Mexico
}

Correspondence should be addressed to Javier Camacho; fcamacho@cinvestav.mx

Received 15 March 2016; Accepted 10 May 2016

Academic Editor: Alexandr V. Bazhin

Copyright (c) 2016 Gabriela Vilema-Enríquez et al. This is an open access article distributed under the Creative Commons Attribution License, which permits unrestricted use, distribution, and reproduction in any medium, provided the original work is properly cited.

\begin{abstract}
Lung cancer has a very high mortality-to-incidence ratio, representing one of the main causes of cancer mortality worldwide. Therefore, new treatment strategies are urgently needed. Several diseases including lung cancer have been associated with the action of reactive oxygen species (ROS) from which hydrogen peroxide $\left(\mathrm{H}_{2} \mathrm{O}_{2}\right)$ is one of the most studied. Despite the fact that $\mathrm{H}_{2} \mathrm{O}_{2}$ may have opposite effects on cell proliferation depending on the concentration and cell type, it triggers several antiproliferative responses. $\mathrm{H}_{2} \mathrm{O}_{2}$ produces both nuclear and mitochondrial DNA lesions, increases the expression of cell adhesion molecules, and increases p53 activity and other transcription factors orchestrating cancer cell death. In addition, $\mathrm{H}_{2} \mathrm{O}_{2}$ facilitates the endocytosis of oligonucleotides, affects membrane proteins, induces calcium release, and decreases cancer cell migration and invasion. Furthermore, the MAPK pathway and the expression of genes related to inflammation including interleukins, TNF- $\alpha$, and NF- $\kappa$ B are also affected by $\mathrm{H}_{2} \mathrm{O}_{2}$. Herein, we will summarize the main effects of hydrogen peroxide on human lung cancer leading to suggesting it as a potential therapeutic tool to fight this disease. Because of the multimechanistic nature of this molecule, novel therapeutic approaches for lung cancer based on the use of $\mathrm{H}_{2} \mathrm{O}_{2}$ may help to decrease the mortality from this malignancy.
\end{abstract}

\section{Introduction}

Lung cancer is one of the main causes of cancer deaths worldwide [1]. Lung cancer can be divided into two major groups according to the pathological classification: small-cell lung cancer (SCLC) and non-small-cell lung cancer (NSCLC). NSCLC is a cancer of epithelial origin that comprises several histological subtypes that differ in their cytology, embryonic origin, anatomical location, and oncogene expression [2]. The most common subtypes of NSCLC are adenocarcinoma (40\% of all forms of lung cancer), squamous cell carcinoma (25 to $30 \%$ ), and large-cell carcinoma (10 to 15\%) [3]. More than 80\% of NSCLC display in many cases high metastatic potential and drug resistance, resulting in poor prognosis even with an early diagnosis [4]. Therefore, new treatment strategies are urgently needed.

Reactive oxygen species (ROS) are radicals, molecules, or ions with a sole unpaired electron in the outermost shell of electrons [5]. They are well known cytotoxic agents involved in the etiology of several human diseases including cancer. 
Accordingly, the expression of ROS detoxifying antioxidant proteins is altered in cancer cells in comparison to normal cells. For instance, thioredoxin reductase, thioredoxin, peroxiredoxin, glutathione S-transferase pi 1, glucose-6-phosphate dehydrogenase, and apurinic/apyrimidinic endonuclease 1/ref-1 (APE1/ref-1) have been found to be increased, while glutamate-cysteine ligase and $\gamma$-glutamyltransferase have been found to be decreased in lung cancer cells [6, 7]. APE1/ref-1 is a key enzyme in base excision repair and in the transcriptional modulation against oxidative stress. APE1/ref-1 is mainly localized in the nucleus of nontumor regions of the lung cancer tissue samples. However, nuclear and cytoplasmic expression of APE1/ref- 1 is markedly upregulated in NSCLC, and the treatment of H460 lung cancer cells with hydrogen peroxide increases APE1/ref-1 expression [7].

ROS are considered potential carcinogens, since they play a role in mutagenesis, cancer promotion, and progression [8]. However, ROS also have anticancer properties by decreasing cell proliferation, damaging DNA, and inducing apoptosis, among other mechanisms. One of the most studied ROS is hydrogen peroxide $\left(\mathrm{H}_{2} \mathrm{O}_{2}\right)$.

\section{Hydrogen Peroxide}

$\mathrm{H}_{2} \mathrm{O}_{2}$ is a protonated form of $\mathrm{O}_{2}{ }^{2-}$ and is produced in biological systems by the dismutation of superoxide anion in a reaction carried out by the enzyme superoxide dismutase (SOD) in the following manner [9]:

$$
\begin{gathered}
\mathrm{M}^{(n+1)+}-\mathrm{SOD}+\mathrm{O}_{2}{ }^{-} \longrightarrow \mathrm{M}^{n+}-\mathrm{SOD}+\mathrm{O}_{2} \\
\mathrm{M}^{n+}-\mathrm{SOD}+\mathrm{O}_{2}{ }^{-}+2 \mathrm{H}^{+} \longrightarrow \mathrm{M}^{(n+1)+}-\mathrm{SOD}+\mathrm{H}_{2} \mathrm{O}_{2},
\end{gathered}
$$

where $\mathrm{M}=\mathrm{Cu}(n=1) ; \mathrm{Mn}(n=2) ; \mathrm{Fe}(n=2) ; \mathrm{Ni}(n=2)$.

$\mathrm{H}_{2} \mathrm{O}_{2}$ is also a soluble lipid and strong oxidizing agent that has been suggested to diffuse throughout the cell membrane via some aquaporins like aquaporin-8, AtTIP1;1, and AtTIP1;2 $[10,11] . \mathrm{H}_{2} \mathrm{O}_{2}$ is also a hypochlorous acid precursor $[9,12]$. This ROS reacts in the presence of transition metals like cupper or iron and produces the hydroxyl radical, a powerful reactive and toxic compound.

One of the preferred targets for $\mathrm{H}_{2} \mathrm{O}_{2}$ is the DNA; it produces single- or double-stranded DNA breaks as well as DNA cross links, in addition to purine, pyrimidine, or deoxyribose modifications [13]. Changes in DNA are usually repaired by the cell, but when persistent DNA damage occurs, then replication errors, genomic instability, activation of oncogenes, and inactivation of tumor suppressor genes might emerge [14]. All of these processes have been associated with the development of a variety of cancers. However, increasing evidence shows that $\mathrm{H}_{2} \mathrm{O}_{2}$ has contrasting effects on cancer cell proliferation depending on its concentration; it generates several antiproliferative responses, induces apoptosis, and inhibits cancer cell migration and invasion.

\section{Effects of $\mathrm{H}_{2} \mathrm{O}_{2}$ on Plasma Membrane and Calcium Mobilization}

Ion channels play important roles in health and disease and $\mathrm{Ca}^{2+}$ signaling is an important second messenger that participates in many processes including proliferation and apoptosis. $\mathrm{H}_{2} \mathrm{O}_{2}$ increases intracellular $\mathrm{Ca}^{2+}$ concentration and decreases electrical resistance in human lung microvascular endothelial cells via activation of TRPV4 ion channels, through a mechanism that requires the Src tyrosine kinase Fyn [15]. In addition, exposure to $\mathrm{H}_{2} \mathrm{O}_{2}$ increases intracellular $\mathrm{Ca}^{2+}$ concentration in rat alveolar type II epithelial cells [16] and induces calcium release from the endoplasmic reticulum in endothelial cells [17]. Ma and collaborators observed that A549 lung cancer cells treated with $\mathrm{H}_{2} \mathrm{O}_{2}(500 \mu \mathrm{M})$ showed an intracellular $\mathrm{Ca}^{2+}$ elevation due to $\mathrm{Ca}^{2+}$ influx and $\mathrm{Ca}^{2+}$ mobilization from intracellular stores. They also describe that $\mathrm{H}_{2} \mathrm{O}_{2}$ increases polyethylenimine/oligonucleotide endocytosis by activating the calcium/calmodulin-dependent protein kinase II (CaMKII). This study suggests that $\mathrm{H}_{2} \mathrm{O}_{2}$ may be useful to improving aerosol oligonucleotide therapy in pulmonary diseases [18]. Zhang et al. also observed that $\mathrm{H}_{2} \mathrm{O}_{2}$ increases the cytoplasmic $\mathrm{Ca}^{2+}$ concentration in A549 cells [19]; this change in calcium concentration might be a critical regulator of apoptosis. Another plasma membrane effect of $\mathrm{H}_{2} \mathrm{O}_{2}$ is on adhesion molecules that are important for permeability and signaling transduction in lung epithelium [20]. When A549 cells were stimulated by $\mathrm{H}_{2} \mathrm{O}_{2}$ the levels of the adhesion molecules CD49f, CD49b, CD29, and CD44 were increased. The expression of these molecules is closely associated with the stress response [21]. The effect of $\mathrm{H}_{2} \mathrm{O}_{2}$ on the plasma membrane and intracellular calcium concentration may be already involved in triggering cell death (Figure 1).

\section{4. $\mathrm{H}_{2} \mathrm{O}_{2}$ Induces Nuclear and Mitochondrial DNA Damage}

Cells are constantly exposed to reactive oxygen species including those metabolically generated as products of aerobic respiration $[32,33]$ and those originated from environmental pollutants [34]. It has been observed that hydrogen peroxide concentrations above $100 \mu \mathrm{M}$ are cytotoxic and genotoxic in A549 cells [35] causing DNA damage [36] and inducing the catalytic activities of DNA topoisomerase complexes [37-39]. Furthermore, the $\mathrm{H}_{2} \mathrm{O}_{2}$-induced damage could be also revealed by the oxidation of DNA bases, for instance, guanine adducts like 8-oxo-7,8-dihydro- $2^{\prime}$-deoxyguanosine (8-oxo-dG) [40]. $\mathrm{H}_{2} \mathrm{O}_{2}$ DNA damage triggers a complex network of DNA damage response (DDR) pathways that may initiate DNA repair, arrest cell cycle progression, and trigger apoptosis. In A549 cells, $\mathrm{H}_{2} \mathrm{O}_{2}$ activates DDR through the Mrell (MRN) complex of proteins (Mre11, Rad50, and $\mathrm{Nbs1}$ ), which are essential for activation of telangiectasia mutated protein kinase (ATM), checkpoint kinase 2 (Chk2), and $\mathrm{H} 2 \mathrm{AX}(\gamma \mathrm{H} 2 \mathrm{AX})$. After Chk2 activation, the cells become arrested at either the G2-M or G1-S transition [41]. Moreover, total $\mathrm{p} 53$ and $\mathrm{p} 21^{\mathrm{Cip} 1 / \text { Waf } 1}$ levels were increased after exposure of A549 cells to $\mathrm{H}_{2} \mathrm{O}_{2}$ [42]. These DNA damage response events induce the formation of DNA damage foci that probably will be activated by stalled replication forks, as well as by the induction of DNA double-strand breaks (DSBs) at the primary DNA lesion sites [43]. It has been described 


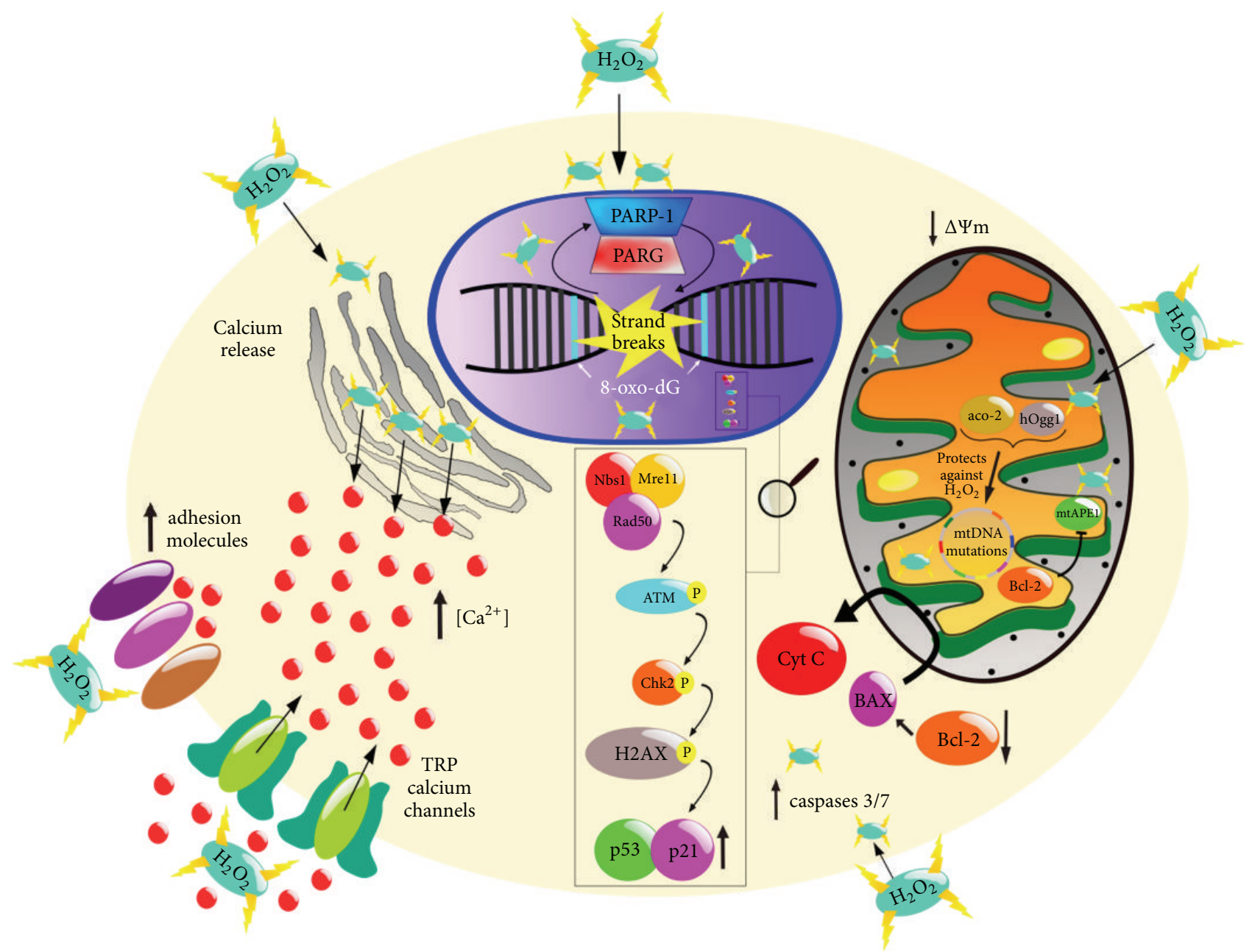

FIgURE 1: Effects of $\mathrm{H}_{2} \mathrm{O}_{2}$ that may lead to cell death. $\mathrm{H}_{2} \mathrm{O}_{2}$ affects several compartments and proteins potentially leading to cell death. Oxidation of DNA bases enriched with guanine adducts like oxo8dG base ring fragmentation, sugar modification, covalent cross linking of DNA and protein, and induction of DNA strand breaks may occur as a result of oxidative DNA damage induced by $\mathrm{H}_{2} \mathrm{O}_{2}$ [22]. Chk2 plays a major role in arresting the cell cycle progression in response to DNA damage [23]. Phosphorylation of Cdc25C and Cdc25A by Chk2 prevents cell cycle progression [24]. DDR involves the activation of the kinases ATM and Chk2 and their downstream effector p53 and its target p21 $1^{\text {Cip } 1 / \text { Waf } 1}$ axis $[25,26]$. Overexpression of Aco-2 reduced oxidant-induced mtDNA lesions, mitochondrial p53 translocation, and apoptosis. Bcl-2 family proteins control the relocalization and actions of cytochrome $\mathrm{C}$, a relevant step of apoptotic cell death [27]. $\mathrm{H}_{2} \mathrm{O}_{2}$ also increases caspase-3/caspase-7 activity [28] and upregulates the cleaved-caspase-9 [27], modifying the $\Delta \Psi \mathrm{m}$ [28]. Apoptosis is also related with increased $\mathrm{Ca}^{2+}$ concentration that may be increased by influx via TRP ion channels or released from intracellular stores [29-31].

that $\mathrm{H}_{2} \mathrm{O}_{2}$ activates poly(ADP-ribose) polymerase (PARP) enzymes when DNA strand breaks have been paired, with the activation of PARP-1 and poly(ADP-ribose) glycohydrolase (PARG), suggesting that this activation process is a survival mechanism. Three members of the 17-member PARP family (PARP-1 to PARP-3) have been shown to be activated by DNA damage. Activated PARP enzymes cleave $\mathrm{NAD}^{+}$into nicotinamide and ADP-ribose from which protein-bound (ADP-ribose)n polymers are synthesized; these polymers label the site of DNA damage enhancing DNA repair and consequently cell survival $[44,45]$. Even though PARP activation has a central role in DNA single-strand break repair, its overactivation can cause cell death if excessive oxidative stress exists (in which DNA damage is severe and irreversible) [44]. On the other hand, repair of some DSBs can be error-prone resulting in deletion of base pairs and other defects that can result in translocations and chromosomal instability [46-49]. The association between DNA oxidation and DNA methylation in A549 cells exposed to $\mathrm{H}_{2} \mathrm{O}_{2}$ has been reported by $\mathrm{Ke}$ et al. Hydrogen peroxide induced the formation of 5methylcytosine $(5-\mathrm{mC})$, which is a cytosine variant produced by the transfer of a methyl group to the carbon located in the fifth position of cytosine. These authors showed that $\mathrm{H}_{2} \mathrm{O}_{2}$ induced decreased levels of DNA methylation in a dosedependent manner, although significant changes in the level of DNA methylation required at least 10 days of exposure to the oxidant. This negative correlation suggests that DNA oxidation may take place before DNA methylation [40].

Not only nuclear DNA (nDNA) but also mitochondrial DNA (mtDNA) can be damaged by hydrogen peroxide. 
The rate of mtDNA mutations may actually be more than two orders of magnitude higher than that of nDNA. Somatic mutations of mtDNA are potentially more harmful for cell physiology compared to somatic damage of nDNA; consequently, the DNA repair systems may play a more important role in the mitochondria than in the nuclei, especially in nondividing cells [50]. This could be explained because mtDNA is in close proximity to the electron transport chain and due to the lack of protective histones [51, 52]. Even though the mechanisms that modulate mtDNA damage are still unclear, Kim et al. suggest that human 8-oxoguanine DNA glycosylase (hOgg1) and aconitase-2 (aco-2) are important factors in limiting oxidant-induced mitochondrial DNA damage. Thus, $\mathrm{H}_{2} \mathrm{O}_{2}$ induces nuclear and mitochondrial DNA damage by several mechanisms [53]. Human APE1 is a major component of the base excision repair in both nDNA and mtDNA [54] in various types of cells, including lung cancer cells $[7,55]$. It has been shown that $\mathrm{Bcl}-2$ suppresses mtDNA repair through direct interaction with APE1 in mitochondria via its $\mathrm{BH}$ domains and inhibition of mtAPE1 endonuclease activity [56]. This led to increased frequency of mtDNA mutations following $\mathrm{H}_{2} \mathrm{O}_{2}$ or nitrosamine 4-(methylnitrosamino)-1-(3pyridyl)-1-butanone (a carcinogen in cigarette smoke) exposure in H1299 human lung cells [56]. Moreover, increased mitochondrial DNA (mtDNA) lesions in A549 cells have been reported after exposure to $\mathrm{H}_{2} \mathrm{O}_{2}$ in a dose-dependent manner; the effect also included a slight reduction in mtDNA copy number [53]. Figure 1 summarizes the effects of $\mathrm{H}_{2} \mathrm{O}_{2}$ on DNA damage.

\section{Paradoxical Effects of $\mathrm{H}_{2} \mathrm{O}_{2}$ on Cancer Cell Proliferation and Migration}

ROS have been proposed to have contrasting effects on cancer models. On one hand, ROS may promote cancer initiation; however, they can also inhibit metastasis of melanoma cells $[57,58]$. Opposite or dual effects for $\mathrm{H}_{2} \mathrm{O}_{2}$ on cancer cell proliferation have also been described. For instance, $\mathrm{H}_{2} \mathrm{O}_{2}$ $(50-200 \mu \mathrm{M})$ inhibits the proliferation of human breast cancer MCF-7 cells [59], but at $1-10 \mu \mathrm{M}$ it increases the proliferation of hepatoma 7721 cells [60]. Interestingly, the proliferation of HT-29 colon cancer cells is enhanced at $10 \mu \mathrm{M}$ whereas a higher concentration $(1000 \mu \mathrm{M})$ leads to apoptosis [61]. $\mathrm{H}_{2} \mathrm{O}_{2}(50 \mu \mathrm{M})$ also produced cell cycle arrest in A549 lung cancer cells; this effect correlated with the downregulation of cyclins D1 and E [62]. Cell migration and invasion are very relevant in cancer progression and malignancy. Opposite effects of $\mathrm{H}_{2} \mathrm{O}_{2}$ on these phenomena have also been observed. The migration of $\mathrm{H} 460$ large lung cancer cells was inhibited by $100 \mu \mathrm{M} \mathrm{H}_{2} \mathrm{O}_{2}$; the superoxide anion and hydrogen peroxide downregulated Cav-1 expression and inhibited cell migration and invasion, whereas the hydroxyl radical upregulated Cav-1 expression and promoted cell migration and invasion. The downregulating effect of superoxide anion and hydrogen peroxide on Cav1 was mediated through a transcription-independent mechanism that involved protein degradation via the ubiquitinproteasome pathway [63]. In H1299, non-small lung cancer cells, $100 \mu \mathrm{M}$ of $\mathrm{H}_{2} \mathrm{O}_{2}$ inhibited migration, upregulated
Deleted in Liver Cancer 1 (DLC1) protein expression, and reduced the activity of RhoA [64]. Thus, $\mathrm{H}_{2} \mathrm{O}_{2}$ may be used as an inhibitor of cancer cell proliferation, migration, and invasion if used at particular concentrations and cancer cell types. The potential use of this ROS as an anticancer agent is also supported by its proapoptotic properties, as the following discussed.

\section{Hydrogen Peroxide Leads to Cell Death/Apoptosis}

DNA damage responses usually end up with the decrease of cell viability and activation of apoptosis pathways depending on the stimulus intensity. $\mathrm{H}_{2} \mathrm{O}_{2}$ induces cell death/apoptosis [65-67] and attenuates cell viability of A549 cells in a concentration- and time-dependent manner [68]. One of the first damage mechanisms induced by oxidative stress is carbonylation of lipids, proteins, and DNA as it has been observed in A549 lung cancer cells [69]. Moreover, $\mathrm{H}_{2} \mathrm{O}_{2}$ decreases intracellular ATP levels and stimulates caspase3/caspase-7 activity [28] and upregulates the expression of cleaved-caspase-9 [27]. This nonradical ROS also affects the mitochondrial membrane potential, closely related to mitochondrial-mediated apoptosis [28]. Cui et al. showed that $\mathrm{H}_{2} \mathrm{O}_{2}$ downregulates the antiapoptotic protein $\mathrm{Bcl}-2$, upregulates the proapoptotic protein BAX, and increases cytochrome C (Cyt C) release from the mitochondria (Figure 1) [27]. It is well known that translocation of BAX from the cytosol to the mitochondria plays a role in the release of mitochondrial proteins [70]. Prolonged dissipation of mitochondrial membrane potential $(\Delta \Psi \mathrm{m})$ might result from mitochondrial DNA damage. Therefore, the upregulation of BAX and the loss of the $\Delta \Psi \mathrm{m}$ produced by $\mathrm{H}_{2} \mathrm{O}_{2}$ may be responsible for the effect of $\mathrm{BAX}$ in the mitochondrial release of Cyt C in A549 cells. Indeed, the apoptotic intrinsic pathway is activated by several mitochondrial proteins released into the cytosol, including Cyt C [71]. In addition to its effects on apoptosis, $\mathrm{H}_{2} \mathrm{O}_{2}(100 \mu \mathrm{M}, 6-24$ hours) induced necrosis in A549 cells [72]. Thus, $\mathrm{H}_{2} \mathrm{O}_{2}$ leads to cell death in different manners. Additionally, this ROS has effects on inflammation, as reviewed in the next section.

\section{Inflammation, ROS, and $\mathrm{H}_{2} \mathrm{O}_{2}$ in Lung Cancer}

Chronic inflammation has been proposed to play a central role in cancer development. Cancer-related inflammation is associated with the proliferation and survival of malignant cells, angiogenesis, tumor metastasis, and tumor response to chemotherapeutic drugs and hormones [73]. Thus, inflammation is a potential target for lung cancer prevention and treatment. Inflammatory cells release a variety of cytokines, chemokines, cytotoxic mediators including ROS, metalloproteinases (MMPs), and membrane-perforating agents, and soluble mediators of cell death, such as TNF- $\alpha$ (Tumor Necrosis Factor- $\alpha$ ), interleukins (IL), and interferons (IFNs) [74]. The tumor stroma of NSCLC is characterized by active angiogenesis and abundant inflammatory infiltrate, which is mainly 
composed of tumor-associated macrophages (TAM). It is also characterized by the presence of tumor infiltrating lymphocytes (TIL), including T, B, and natural killer (NK) cells, and tumor-associated neutrophils (TAN) $[75,76]$. Several important molecules involved in the inflammatory response are regulated by or have been associated with $\mathrm{ROS}$ and $\mathrm{H}_{2} \mathrm{O}_{2}$.

7.1. TGF $\beta$. Transforming growth factor $\beta(\operatorname{TGF} \beta)$ is an immunosuppressive cytokine [77] that has a pleiotropic role in tumor biology and is frequently overexpressed in many cancers, including NSCLC [78-80]. TGF $\beta$ affects cell growth, proliferation, differentiation, and apoptosis [81]. High expression of TGF $\beta$ is a poor survival predictor in NSCLC [79]. Treatment of human malignant mesothelioma cells (HMM) with $\mathrm{H}_{2} \mathrm{O}_{2}$ promoted the epithelial-mesenchymal transition, as indicated by increased expression levels of vimentin, SLUG, and TWIST1 and decreased E-cadherin. Expression of stemness genes such as OCT4, SOX2, and NANOG was also significantly increased in $\mathrm{HMM}$ cells treated with $\mathrm{H}_{2} \mathrm{O}_{2}$. These gene expression changes were mediated via activation of hypoxia inducible factor 1 alpha (HIF-1 $\alpha$ ) and TGF- $\beta 1$ [82] .

7.2. Interleukins. Interleukin-10 (IL-10) is a multifunctional cytokine with both immunosuppressive and antiangiogenic functions; thus, it has both tumor-promoting and tumorinhibiting properties [83]. Increased serum and peritumoral IL-10 levels have been reported in several malignancies [84], including lung cancer [83], suggesting a role for IL-10 in the tumor escape from the immune response. High IL-10 expression and increased serum concentrations of IL-10 in NSCLC patients have been shown to correlate with reduced survival [83]. IL-10 serum levels are higher in patients with metastatic disease in contrast to patients with localized tumors [85]. IL10 favors tumor malignancy by promoting $\mathrm{T}$ cell apoptosis and tumor cell survival [86]. In lung carcinomas, IL-10 inhibits tumor cell susceptibility to cytotoxic T-lymphocytemediated killing [87]. Transgenic mice overexpressing IL-10 developed larger tumors than control mice when injected with Lewis lung carcinoma cells, suggesting that the production of IL-10 prevents a full immune response against the tumor cells [88]. IL-6 is of particular interest because it is expressed in malignant epithelial cells, and their expression is associated with a poor prognosis in lung cancer patients [89]. This interleukin has been detected in primary squamous cell carcinomas, adenocarcinomas, and several tumor cell lines [90, 91]. In a study with lung cancer patients, increased serum levels of IL- 6 were found in 39\% of the patients, whereas it was not detected in the serum of healthy controls or in patients with benign lung diseases [90,92]. Bihl and coworkers demonstrated that IL- 6 may be required for the proper control of cell proliferation in a subset of NSCLC cell lines. Two cell subgroups were reported in this study: NSCLC IL-6-dependent and IL-6-independent cells; this finding may have interesting clinical implications [93]. Paradoxically, antitumor effects of IL-6 have been demonstrated in vitro and in vivo, as well as in human biopsies from NSCLC and breast cancer [90]. TNF- $\alpha$ induced IL- 8 gene expression in H441 lung epithelial cells by activating the IL- 8 promoter via recruitment of NF- $\kappa$ B to a TNF- $\alpha$ response element [94].
Similar results were obtained with lung adenocarcinoma GLC-82 cells treated with $\mathrm{H}_{2} \mathrm{O}_{2}(0.5 \mathrm{mM})$ [95]. In addition, $\mathrm{Hsu}$ et al. described that A549 lung cancer cells treated with $\mathrm{H}_{2} \mathrm{O}_{2}$ showed reduced I- $\kappa \beta$ expression with a concomitant increase in NF- $\kappa \mathrm{B}$ and IL-8 expression [21].

7.3. NF- $\kappa B$. NF- $\kappa \mathrm{B}$ is a positive mediator of cell growth and proliferation as well as a critical signaling molecule in $\mathrm{H}_{2} \mathrm{O}_{2}$ induced inflammation. NF- $\kappa \mathrm{B}$ increases the expression of several components involved in cell cycle progression including cyclins D and E. However, the contributions of NF- $\kappa \mathrm{B}$ to lung cancer development are complex, and the underlying mechanisms are not fully understood [96]. Tumor biopsies from lung cancer patients showed high levels of NF- $\kappa \mathrm{B}$ activation in both SCLC and NSCLC and were significantly associated with TNM (tumor size, node status, and metastasis) stages and poor prognosis [96]. Interestingly, inhibiting NF- $\kappa$ B with either siRNA, IKK inhibitors, or IKK suppressors inhibited lung cancer cell survival and proliferation $[96,97]$. $\mathrm{H}_{2} \mathrm{O}_{2}$ activates cytosolic phosphorylation of NF- $\kappa \mathrm{B}$ p65 and ERK1/2 and induces nuclear translocation of pNF- $\kappa \mathrm{B}$ p65 producing inflammatory damage in A549 lung cancer cells. The genes involved in this response of the NF- $\kappa \mathrm{B}$ and MAPK signaling pathways included IL- $1 \beta$, IL-6, IL- 8 , TNF- $\alpha$, MCP1, IP-10, and MIP [98].

7.4. MMPs. MMPs are a family of proteolytic enzymes that are capable of degrading various components of the extracellular matrix [99]. They are involved in all stages of cancer progression, not only in the process of tumor invasion and metastasis [100], but also in the proliferation, adhesion, migration, differentiation, angiogenesis, senescence, autophagy, apoptosis, and evasion of the immune system [101, 102]. Several studies have reported that plasma and/or serum levels of MMP-9 and TIMP-1 are elevated in stage III/IV lung cancer patients, when compared with patients with nonmalignant lung diseases $[103,104]$. Retrospective studies of NSCLC tissue found that MMP-7 expression was higher in squamous cell carcinomas than in adenocarcinomas and correlated with significantly lower overall survival in patients [105]. MMP9 is not produced by resident cells in the normal lung, but bronchial epithelial cells, alveolar type II cells, fibroblasts, smooth muscle cells, and endothelial cells produce MMP-9 in response to diverse stimuli [106]. Leukocytes in the lung can also be a source of MMP-9. Macrophages, eosinophils, mast cells, lymphocytes, NK cells, and dendritic cells all are able to produce MMP-9 [106]. Lung cancer cells, both primary and metastatic, can express MMP- 9 constitutively, which may correlate with metastatic potential [106-108].

The transcription factor Ets-1 was found to be associated with the progression of several human cancers including NSCL [109]. Ets-1 may upregulate MMP-9 expression triggered by TGF-betal and TPA via MAPK signaling [110]. $\mathrm{H}_{2} \mathrm{O}_{2}$ upregulates Ets-1 via an antioxidant response element in the promoter, suggesting its potential role in ROS-triggered tumor progression [111]. Interestingly, $\mathrm{H}_{2} \mathrm{O}_{2}$ induced MMP-2 and MMP-9 expression in the lung adenocarcinoma cell line GLC-82, as well as of several components activated by the innate immune response including MyD88, TRAF2, TRAF6, 
and TRADD [95]. The association of ROS with inflammation might be used to suggest combined treatments of $\mathrm{H}_{2} \mathrm{O}_{2}$ with anti-inflammatory drugs in cancer therapy.

\section{Potential $\mathrm{H}_{2} \mathrm{O}_{2}$-Based Therapeutic Strategies and Implications}

Herein we described that hydrogen peroxide has several effects on lung cancer cells including DNA damage, cell cycle arrest, apoptosis, migration, and inflammation. Because many of these mechanisms end up with cell death, cautious delivery of $\mathrm{H}_{2} \mathrm{O}_{2}$ may be used as a potential therapeutic tool to treat some disorders including lung cancer. Actually, opposite effects of $\mathrm{H}_{2} \mathrm{O}_{2}$ may be also used in favor of some conditions. For instance, $\mathrm{H}_{2} \mathrm{O}_{2}(30 \mu \mathrm{M})$ induced the migration of A549 cells, showing that the exposure to low concentrations of hydrogen peroxide may benefit tissue repair during acute lung injury [112]. Furthermore, $\mathrm{H}_{2} \mathrm{O}_{2}$ has been used to enhance the adhesion of hematopoietic stem/progenitor cells when systemically administered in inflammatory bowel disorders [113].

A few years ago, a hydrogen peroxide-generating system emerged as an interesting anticancer alternative strategy to selectively kill cancer cells. As cancer cells generate high concentrations of ROS and are under increased intrinsic oxidative stress, they might be more vulnerable to further oxidative insults produced by ROS-generating agents [114]. In malignant cells, prooxidant changes induce a redox shift that turns the cancer cell proliferative machinery on, leading to functional impairment, cell cycle arrest, and finally cell death. Even if the direct administration of $\mathrm{H}_{2} \mathrm{O}_{2}$ to cancer patients is not an accepted therapeutic strategy, there is now convincing evidence that $\mathrm{H}_{2} \mathrm{O}_{2}$-generating systems might be an efficient way of killing cancer cells [115]. For instance, $\mathrm{H}_{2} \mathrm{O}_{2}$ can selectively induce apoptosis in cancer cells and mediate, at least in part, the activity of several anticancer drugs including paclitaxel, doxorubicin, cisplatin, casiopeínas, and arsenic trioxide since these drugs generate ROS as a potential mode of action, increasing the rate of cancer cell death [116]. Actually, $\mathrm{H}_{2} \mathrm{O}_{2}$ seems to play an important role in oxidative stressinduced cancer cell death $[115,117] . \mathrm{H}_{2} \mathrm{O}_{2}$ produced in the mitochondria is able to induce cell cycle arrest and senescence, a combination that might suppress tumor growth when sublethal concentrations of ROS are generated in response to therapy [118]. Not only synthetic products but also natural compounds have been described as promising candidates to potentially increase ROS levels and attack a wide variety of cancer cells. For instance, the codrug BetCA (a chemical combination of dichloroacetate and betulinic acid) increases ROS production and significantly alters mitochondrial membrane potential gradient $(\Delta \Psi \mathrm{m})$, followed by the release of Cyt $\mathrm{C}$ which prompts cells to undergo mitochondria mediated apoptosis [119].

Recently, cold atmospheric or nonthermal plasma has been suggested as an alternative therapy for different types of cancers with promising results obtained in vitro $[120,121]$ as well as in vivo $[122,123]$. Nonthermal plasma can be produced by ionizing neutral gas molecules/atoms, which leads to a highly reactive gas at room temperature. This gas contains excited molecules and reactive species, among its most important constituents [123]. The therapeutic effects of nonthermal plasma result from the generation of ROS, which lead to $\Delta \Psi \mathrm{m}$, mitochondrial ROS accumulation, changes in the cell cycle, expression of DNA damage markers like $\gamma \mathrm{H} 2 \mathrm{AX}$, and finally induction of apoptosis [120, 121, 123]. Nonthermal plasma decreases the intracellular ATP concentration and the viability of A549 cells. It also increases the number of apoptotic cells due to caspase activation. In addition, plasma alters the mitochondrial membrane potential, regulates the mRNA levels of BAX, BAX1, H2AX, and Bcl-2, and modifies phosphorylated ERK1/2/MAPK protein levels [28].

Panieri et al. demonstrated that NSCLC cells resistant to conventional anticancer treatment can be sensitized in the presence of either high levels of $\mathrm{H}_{2} \mathrm{O}_{2}(48 \mu \mathrm{M})$ resulting in DNA damage and irreversible ATP depletion (caspaseindependent) or lower $\mathrm{H}_{2} \mathrm{O}_{2}$ concentrations $(6.5 \mu \mathrm{M})$ which induces inhibition of glycolysis and abrogation of ATP restoring mechanisms. Thus, cancers not responding to conventional therapies may be evaluated for their response to different $\mathrm{H}_{2} \mathrm{O}_{2}$ concentrations. Despite the fact that $\mathrm{H}_{2} \mathrm{O}_{2}$ may activate the inflammatory response potentially leading to cancer, the combined use of $\mathrm{H}_{2} \mathrm{O}_{2}$ with anti-inflammatory drugs may preserve the anticancer effect of this ROS and overwhelm the potential inflammatory response improving the anticancer treatment.

Recently, several drugs indicated for other diseases have been shown to have antiproliferative properties and have been suggested as an alternative therapy for different malignancies including lung cancer [124]. Thus, the novel combination of $\mathrm{H}_{2} \mathrm{O}_{2}$ with such repositioned drugs represents a new research area in cancer therapy.

\section{Conclusions}

Because of the multimechanistic and multitarget anticancer properties of $\mathrm{H}_{2} \mathrm{O}_{2}$, this molecule is a very interesting potential therapeutic tool to fight cancer (Figure 2). The proper and cautious use of $\mathrm{H}_{2} \mathrm{O}_{2}$ in combination with commonly used chemotherapeutic drugs may have synergistic effects increasing lung cancer cell death. Particularly, novel therapeutic approaches combining $\mathrm{H}_{2} \mathrm{O}_{2}$ with repositioned drugs may help to decrease the mortality from this malignancy.

\section{Abbreviations}

aco-2: Aconitase-2

APE1/ref-1: Apurinic/apyrimidinic endonuclease 1/ref-1

APE1: $\quad$ Purinic/apyrimidinic (AP) endonuclease 1

ATM: Activation of telangiectasia mutated protein kinase

ATP: $\quad$ Adenosine triphosphate

Bcl-2: $\quad$ B cell lymphoma 2

CaMKII: Calcium/calmodulin-dependent protein

kinase II

Cav-1: Caveolin-1

CD49f: Cluster of differentiation

CDKs: Cyclin dependent kinases

Chk2: Checkpoint kinase 2 


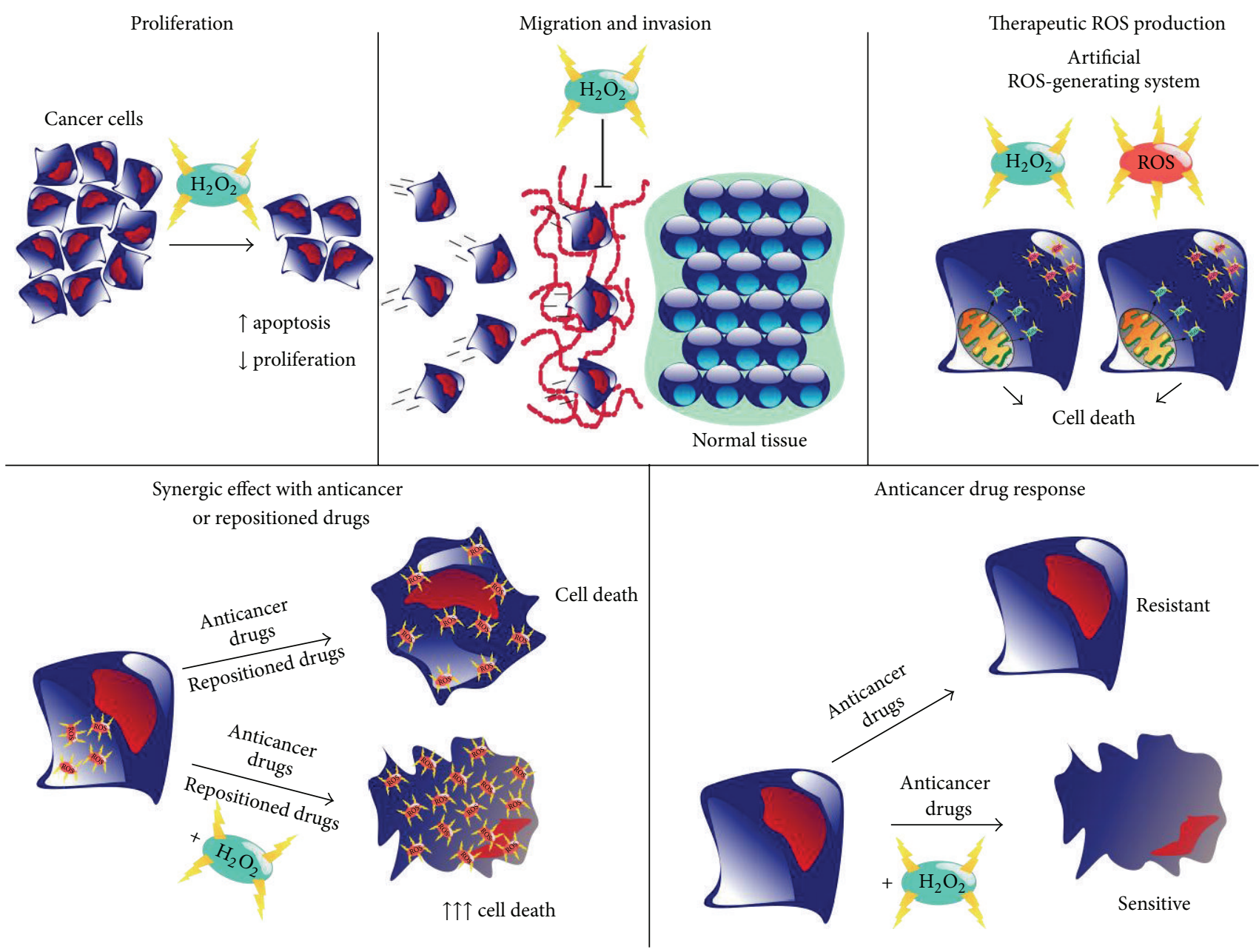

Figure 2: Potential therapeutic use of $\mathrm{H}_{2} \mathrm{O}_{2}$ to fight lung cancer. $\mathrm{H}_{2} \mathrm{O}_{2}$ can decrease the proliferation and increase the apoptosis of lung cancer cells. In addition, metastasis may be prevented because of the inhibitory effects of $\mathrm{H}_{2} \mathrm{O}_{2}$ in cell migration and invasion. Artificial ROS- $\mathrm{H}_{2} \mathrm{O}_{2}$ production directed to cancer cells in an excessive manner may lead also to cell death. $\mathrm{H}_{2} \mathrm{O}_{2}$ may also increase the cytotoxicity of anticancer drugs and revert drug resistance, as well as potentiating the effect of repositioned drugs with anticancer effects.

Cyt C: Cytochrome C

DDR: DNA damage response

DLC1: Deleted in Liver Cancer 1

DSBs: DNA double-strand breaks

ERK1/2: Extracellular-signal-regulated kinases

Fyn: $\quad$ Nonreceptor tyrosine kinase

H2AX: Histone family, member X

$\mathrm{H}_{2} \mathrm{O}_{2}$ : Hydrogen peroxide

HIF-1 $\alpha$ : Hypoxia inducible factor 1 alpha

HMM: Human malignant mesothelioma cells

hOggl: Human 8-oxoguanine DNA glycosylase

IFNs: Interferons

IKK: IkB kinase

IL: $\quad$ Interleukins

IP-10: Interferon gamma-induced protein 10

MCP-1: Monocyte chemotactic protein 1

MIP: Macrophage Inflammatory Proteins

MMPs: Metalloproteinases

MRN: Complex of Mre11, Rad50, and Nbs1 proteins mtDNA: Mitochondrial DNA
nDNA: Nuclear DNA

Nbsl: Nibrin

NF- $\kappa$ B: Nuclear factor kappa-light-chain-enhancer of activated B cells

NK: Natural killer

NSCLC: Non-small-cell lung cancer

OCT4: Octamer-binding transcription factor 4

PARG: Poly(ADP-ribose) glycohydrolase

PARP: Poly(ADP-ribose) polymerase

Rad50: Double-strand break repair protein

ROS: Reactive oxygen species

SCLC: Small-cell lung cancer

siRNA: Small interfering RN

SOD: Superoxide dismutase

SOX2: Sex determining region Y-box 2

Src: $\quad$ Nonreceptor tyrosine kinase

TAM: Tumor-associated macrophages

TAN: Tumor-associated neutrophils

TGF $\beta$ : Transforming growth factor- $\beta$

TIL: $\quad$ Tumor infiltrating lymphocytes 
TIMP-1: Tissue metallopeptidase inhibitor

TNF- $\alpha$ : Tumor Necrosis Factor- $\alpha$

TRPV4: Transient receptor potential cation channel subfamily $\mathrm{V}$ member 4

$\Delta \Psi \mathrm{m}: \quad$ Mitochondrial membrane potential.

\section{Disclosure}

Gabriela Vilema-Enríquez is a recipient of a doctoral scholarship from the Ecuadorian government through the Secretariat for Higher Education, Science, Technology and Innovation (SENESCYT).

\section{Competing Interests}

The authors declare that they have no competing interests.

\section{Authors' Contributions}

Gabriela Vilema-Enríquez and Aurora Arroyo contributed equally to this work.

\section{References}

[1] World Health Organization, The Top 10 Causes of Death, World Health Organization, Geneva, Switzerland, 2014, http://www .who.int/mediacentre/factsheets/fs310/en/.

[2] W. D. Travis, "Pathology of lung cancer," Clinics in Chest Medicine, vol. 23, no. 1, pp. 65-81, 2002.

[3] J. R. Molina, P. Yang, S. D. Cassivi, S. E. Schild, and A. A. Adjei, "Non-small cell lung cancer: epidemiology, risk factors, treatment, and survivorship," Mayo Clinic Proceedings, vol. 83, no. 5, pp. 584-594, 2008.

[4] G. Zalcman, E. Bergot, and E. Lechapt, "Update on nonsmall cell lung cancer," European Respiratory Review, vol. 19, no. 117, pp. 173-185, 2010.

[5] G.-Y. Liou and P. Storz, "Reactive oxygen species in cancer," Free Radical Research, vol. 44, no. 5, pp. 479-496, 2010.

[6] R. Tobe, B. Carlson, P. Tsuji, B. Lee, V. Gladyshev, and D. Hatfield, "Differences in redox regulatory systems in human lung and liver tumors suggest different avenues for therapy," Cancers, vol. 7, no. 4, pp. 2262-2276, 2015.

[7] D. G. Yoo, Y. J. Song, E. J. Cho et al., "Alteration of APE1/ref1 expression in non-small cell lung cancer: the implications of impaired extracellular superoxide dismutase and catalase antioxidant systems," Lung Cancer, vol. 60, no. 2, pp. 277-284, 2008.

[8] G. Waris and H. Ahsan, "Reactive oxygen species: role in the development of cancer and various chronic conditions," Journal of Carcinogenesis, vol. 5, article 14, 2006.

[9] G. Manda, M. T. Nechifor, and T.-M. Neagu, "Reactive oxygen species, cancer and anti-cancer therapies," Current Chemical Biology, vol. 3, no. 1, pp. 22-46, 2009.

[10] G. P. Bienert, A. L. B. Møller, K. A. Kristiansen et al., "Specific aquaporins facilitate the diffusion of hydrogen peroxide across membranes," The Journal of Biological Chemistry, vol. 282, no. 2, pp. 1183-1192, 2007.

[11] A. C. Montezano and R. M. Touyz, "Information of the Editorial is now provided," in Reactive Oxygen Species and theCardiovascular System, Morgan and Claypool, Life Sciences, San Rafael, Calif, USA, 2012.
[12] V. J. Thannickal and B. L. Fanburg, "Reactive oxygen species in cell signaling," American Journal of Physiology-Lung Cellular and Molecular Physiology, vol. 279, no. 6, pp. L1005-L1028, 2000.

[13] B. Halliwell and J. Gutteridge, Free Radicals in Biology and Medicine, Oxford University Press, Oxford, UK, 2015.

[14] S. Negrini, V. G. Gorgoulis, and T. D. Halazonetis, "Genomic instability an evolving hallmark of cancer," Nature Reviews Molecular Cell Biology, vol. 11, no. 3, pp. 220-228, 2010.

[15] K. Suresh, L. Servinsky, J. Reyes et al., "Hydrogen peroxideinduced calcium influx in lung microvascular endothelial cells involves TRPV4," American Journal of Physiology-Lung Cellular and Molecular Physiology, vol. 309, no. 12, pp. L1467-L1477, 2015.

[16] K. L. Rice, P. G. Duane, S. L. Archer, D. P. Gilboe, and D. E. Niewoehner, " $\mathrm{H}_{2} \mathrm{O}_{2}$ injury causes $\mathrm{Ca}^{2+}$-dependent and independent hydrolysis of phosphatidylcholine in alveolar epithelial cells," American Journal of Physiology-Lung Cellular and Molecular Physiology, vol. 263, no. 4, pp. L430-L438, 1992.

[17] T. Volk, M. Hensel, and W. J. Kox, “Transient $\mathrm{Ca}^{2+}$ changes in endothelial cells induced by low doses of reactive oxygen species: role of hydrogen peroxide," Molecular and Cellular Biochemistry, vol. 171, no. 1-2, pp. 11-21, 1997.

[18] Z. Ma, W. W. Sun, and X. Wang, "Hydrogen peroxide enhances the uptake of polyethylenimine/oligonucleotide complexes in A549 cells by activating CaMKII independent of [ca2+]c elevation," Genetics and Molecular Research, vol. 13, no. 2, pp. 29142921, 2014.

[19] S. Zhang, C. Li, J. Gao, X. Qiu, and Z. Cui, "[Application of the $\mathrm{Ca}^{2+}$ indicator fluo-3 and fluo- 4 in the process of $\mathrm{H}_{2} \mathrm{O}_{2}$ induced apoptosis of A549 cell]," Chinese Journal of Lung Cancer, vol. 17, no. 3, pp. 197-202, 2014.

[20] A. Laitinen and L. A. Laitinen, "Airway morphology: epithelium/basement membrane," American Journal of Respiratory and Critical Care Medicine, vol. 150, no. 5, pp. S14-S17, 1994.

[21] J.-Y. Hsu, J.-J. Chu, M.-C. Chou, and Y.-W. Chen, "Dioscorin pre-treatment protects A549 human airway epithelial cells from hydrogen peroxide-induced oxidative stress," Inflammation, vol. 36, no. 5, pp. 1013-1019, 2013.

[22] K. B. Beckman and B. N. Ames, "Oxidative decay of DNA," Journal of Biological Chemistry, vol. 272, no. 32, pp. 19633-19636, 1997.

[23] B.-B. S. Zhou and S. J. Elledge, "The DNA damage response: putting checkpoints in perspective," Nature, vol. 408, no. 6811, pp. 433-439, 2000.

[24] C.-Y. Peng, P. R. Graves, R. S. Thoma, Z. Wu, A. S. Shaw, and H. Piwnica-Worms, "Mitotic and G2 checkpoint control: regulation of 14-3-3 protein binding by phosphorylation of Cdc25c on serine-216," Science, vol. 277, no. 5331, pp. 1501-1505, 1997.

[25] J. Bartkova, N. Rezaei, M. Liontos et al., "Oncogene-induced senescence is part of the tumorigenesis barrier imposed by DNA damage checkpoints," Nature, vol. 444, no. 7119, pp. 633-637, 2006.

[26] J. Campisi and F. D. A. di Fagagna, "Cellular senescence: when bad things happen to good cells," Nature Reviews Molecular Cell Biology, vol. 8, no. 9, pp. 729-740, 2007.

[27] J. Cui, H. Zhao, C. Wang, J. J. Sun, K. Lu, and D. Ma, "Dexmedetomidine attenuates oxidative stress induced lung alveolar epithelial cell apoptosis in vitro," Oxidative Medicine and Cellular Longevity, vol. 2015, Article ID 358396, 11 pages, 2015. 
[28] N. Kaushik, N. Uddin, G. B. Sim et al., "Responses of solid tumor cells in DMEM to reactive oxygen species generated by nonthermal plasma and chemically induced ROS systems," Scientific Reports, vol. 5, article 8587, 2015.

[29] I. Kruman, Q. Guo, and M. P. Mattson, "Calcium and reactive oxygen species mediate staurosporine-induced mitochondrial dysfunction and apoptosis in PC12 cells," Journal of Neuroscience Research, vol. 51, no. 3, pp. 293-308, 1998.

[30] B. Tombal, S. R. Denmeade, and J. T. Isaacs, "Assessment and validation of a microinjection method for kinetic analysis of $[\mathrm{Ca} 2+](\mathrm{i})$ in individual cells undergoing apoptosis," Cell Calcium, vol. 25, no. 1, pp. 19-28, 1999.

[31] K. Lynch, G. Fernandez, A. Pappalardo, and J. J. Peluso, "Basic fibroblast growth factor inhibits apoptosis of spontaneously immortalized granulosa cells by regulating intracellular free calcium levels through a protein kinase $\mathrm{C} \delta$-dependent pathway," Endocrinology, vol. 141, no. 11, pp. 4209-4217, 2000.

[32] M. M. Vilenchik and A. G. Knudson, "Endogenous DNA double-strand breaks: production, fidelity of repair, and induction of cancer," Proceedings of the National Academy of Sciences of the United States of America, vol. 100, no. 22, pp. 12871-12876, 2003.

[33] H. Zhao, T. Tanaka, H. D. Halicka et al., "Cytometric assessment of DNA damage by exogenous and endogenous oxidants reports aging-related processes," Cytometry Part A, vol. 71, no. 11, pp. 905-914, 2007.

[34] E. Taioli, R. J. Sram, S. Garte, I. Kalina, T. A. Popov, and P. B. Farmer, "Effects of polycyclic aromatic hydrocarbons (PAHs) in environmental pollution on exogenous and oxidative DNA damage (EXPAH project): description of the population under study," Mutation Research-Fundamental and Molecular Mechanisms of Mutagenesis, vol. 620, no. 1-2, pp. 1-6, 2007.

[35] S. Sharma, V. Venkatesan, B. M. Prakhya, and R. Bhonde, "Human mesenchymal stem cells as a novel platform for simultaneous evaluation of cytotoxicity and genotoxicity of pharmaceuticals," Mutagenesis, vol. 30, no. 3, Article ID geu086, pp. 391-399, 2015.

[36] L. Marabini, R. Calò, and P. C. Braga, "Protective effect of erdosteine metabolite I against hydrogen peroxide-induced oxidative DNA-damage in lung epithelial cells," ArzneimittelForschung, vol. 61, no. 12, pp. 700-706, 2011.

[37] T.-K. Li, A. Y. Chen, C. Yu, Y. Mao, H. Wang, and L. F. Liu, "Activation of topoisomerase II-mediated excision of chromosomal DNA loops during oxidative stress," Genes \& Development, vol. 13, no. 12, pp. 1553-1560, 1999.

[38] P. Daroui, S. D. Desai, T.-K. Li, A. A. Liu, and L. F. Liu, "Hydrogen peroxide induces topoisomerase I-mediated DNA damage and cell death," The Journal of Biological Chemistry, vol. 279, no. 15, pp. 14587-14594, 2004.

[39] M. López-Lázaro, J. M. Calderón-Montaño, E. Burgos-Morón, and C. A. Austin, "Green tea constituents (-)-epigallocatechin3-gallate (EGCG) and gallic acid induce topoisomerase I- and topoisomerase II-DNA complexes in cells mediated by pyrogallol-induced hydrogen peroxide," Mutagenesis, vol. 26, no. 4, pp. 489-498, 2011.

[40] Y. Ke, X. Xu, S. Mei, X. Xie, and G. Tao, "The association of DNA methylation and DNA oxidation induced by $\mathrm{H}_{2} \mathrm{O}_{2}$," Chinese Journal of Industrial Hygiene and Occupational Diseases, vol. 32, no. 1, pp. 50-54, 2014.
[41] H. Zhao, F. Traganos, A. P. Albino, and Z. Darzynkiewicz, "Oxidative stress induces cell cycle-dependent Mrell recruitment, ATM and Chk2 activation and histone H2AX phosphorylation," Cell Cycle, vol. 7, no. 10, pp. 1490-1495, 2008.

[42] A. Sfikas, C. Batsi, E. Tselikou et al., "The canonical NF- $\kappa$ B pathway differentially protects normal and human tumor cells from ROS-induced DNA damage," Cellular Signalling, vol. 24, no. 11, pp. 2007-2023, 2012.

[43] H. Zhao, J. Dobrucki, P. Rybak, F. Traganos, H. Dorota Halicka, and Z. Darzynkiewicz, "Induction of DNA damage signaling by oxidative stress in relation to DNA replication as detected using 'click chemistry"' Cytometry Part A, vol. 79, no. 11, pp. 897-902, 2011.

[44] K. Kovács, K. Erdélyi, C. Hegeds et al., "Poly(ADP-ribosyl)ation is a survival mechanism in cigarette smoke-induced and hydrogen peroxide-mediated cell death," Free Radical Biology and Medicine, vol. 53, no. 9, pp. 1680-1688, 2012.

[45] K. Erdélyi, P. Pacher, L. Virág, and C. Szabó, "Role of poly(ADPribosyl)ation in a 'two-hit' model of hypoxia and oxidative stress in human A549 epithelial cells in vitro," International Journal of Molecular Medicine, vol. 32, no. 2, pp. 339-346, 2013.

[46] V. Gorbunova and A. Seluanov, "Making ends meet in old age: DSB repair and aging," Mechanisms of Ageing and Development, vol. 126, no. 6-7, pp. 621-628, 2005.

[47] Z. E. Karanjawala and M. R. Lieber, "DNA damage and aging," Mechanisms of Ageing and Development, vol. 125, no. 6, pp. 405416, 2004.

[48] E. Pastwa and J. Błasiak, "Non-homologous DNA end joining," Acta Biochimica Polonica, vol. 50, no. 4, pp. 891-908, 2003.

[49] P. A. Jeggo and M. Löbrich, "Artemis links ATM to double strand break rejoining," Cell Cycle, vol. 4, no. 3, pp. 359-362, 2005.

[50] I. N. Todorov and G. I. Todorov, "Multifactorial nature of high frequency of mitochondrial DNA mutations in somatic mammalian cells," Biochemistry, vol. 74, no. 9, pp. 962-970, 2009.

[51] B. Van Houten, V. Woshner, and J. H. Santos, "Role of mitochondrial DNA in toxic responses to oxidative stress," DNA Repair, vol. 5, no. 2, pp. 145-152, 2006.

[52] T. R. Figueira, M. H. Barros, A. A. Camargo et al., "Mitochondria as a source of reactive oxygen and nitrogen species: from molecular mechanisms to human health," Antioxidants and Redox Signaling, vol. 18, no. 16, pp. 2029-2074, 2013.

[53] S.-J. Kim, P. Cheresh, D. Williams et al., "Mitochondria-targeted Ogg1 and aconitase-2 prevent oxidant-induced mitochondrial DNA damage in alveolar epithelial cells," The Journal of Biological Chemistry, vol. 289, no. 9, pp. 6165-6176, 2014.

[54] B. Karahalil, B. A. Hogue, N. C. De Souza-Pinto, and V. A. Bohr, "Base excision repair capacity in mitochondria and nuclei: tissue-specific variations," The FASEB Journal, vol. 16, no. 14, pp. 1895-1902, 2002.

[55] G. Tell, G. Damante, D. Caldwell, and M. R. Kelley, "The intracellular localization of APE1/Ref-1: more than a passive phenomenon?" Antioxidants \& Redox Signaling, vol. 7, no. 3-4, pp. 367-384, 2005.

[56] M. Xie, P. W. Doetsch, and X. Deng, "Bcl2 inhibition of mitochondrial DNA repair," BMC Cancer, vol. 15, no. 1, pp. 1-12, 2015.

[57] E. Piskounova, M. Agathocleous, M. M. Murphy et al., "Oxidative stress inhibits distant metastasis by human melanoma cells," Nature, vol. 527, no. 7577, pp. 186-191, 2015. 
[58] I. S. Harris and J. S. Brugge, "Cancer: the enemy of my enemy is my friend," Nature, vol. 527, no. 7577, pp. 170-171, 2015.

[59] P.-J. Chua, G. W.-C. Yip, and B.-H. Bay, "Cell cycle arrest induced by hydrogen peroxide is associated with modulation of oxidative stress related genes in breast cancer cells," Experimental Biology and Medicine, vol. 234, no. 9, pp. 1086-1094, 2009.

[60] S.-L. Liu, X. Lin, D.-Y. Shi, J. Cheng, C.-Q. Wu, and Y.-D. Zhang, "Reactive oxygen species stimulated human hepatoma cell proliferation via cross-talk between PI3-K/PKB and JNK signaling pathways," Archives of Biochemistry and Biophysics, vol. 406, no. 2, pp. 173-182, 2002.

[61] I.-J. Park, J.-T. Hwang, M. K. Young, J. Ha, and J. P. Ock, “Differential modulation of AMPK signaling pathways by low or high levels of exogenous reactive oxygen species in colon cancer cells," Annals of the New York Academy of Sciences, vol. 1091, no. 1, pp. 102-109, 2006.

[62] D. Upadhyay, W. Chang, K. Wei, M. Gao, and G. D. Rosen, "Fibroblast growth factor-10 prevents $\mathrm{H}_{2} \mathrm{O}_{2}$-induced cell cycle arrest by regulation of G1 cyclins and cyclin dependent kinases," FEBS Letters, vol. 581, no. 2, pp. 248-252, 2007.

[63] S. Luanpitpong, S. J. Talbott, Y. Rojanasakul et al., "Regulation of lung cancer cell migration and invasion by reactive oxygen species and caveolin-1," The Journal of Biological Chemistry, vol. 285, no. 50, pp. 38832-38840, 2010.

[64] L. Ma, W.-Z. Zhu, T.-T. Liu et al., " $\mathrm{H}_{2} \mathrm{O}_{2}$ inhibits proliferation and mediates suppression of migration via DLC1/RhoA signaling in cancer cells," Asian Pacific Journal of Cancer Prevention, vol. 16, no. 4, pp. 1637-1642, 2015.

[65] J.-P. Chen, D.-G. Xu, X.-Y. Yu et al., "Discrepancy between the effects of morronside on apoptosis in human embryonic lung fibroblast cells and lung cancer A549 cells," Oncology Letters, vol. 7, no. 4, pp. 927-932, 2014.

[66] H. Su, D.-D. Liu, M. Zhao et al., "Dual-enzyme characteristics of polyvinylpyrrolidone-capped iridium nanoparticles and their cellular protective effect against $\mathrm{H}_{2} \mathrm{O}_{2}$-induced oxidative damage," ACS Applied Materials and Interfaces, vol. 7, no. 15, pp. 8233-8242, 2015.

[67] Y. I. Chirino, Y. Sánchez-Pérez, Á. R. Osornio-Vargas et al., " $\mathrm{PM}_{10}$ impairs the antioxidant defense system and exacerbates oxidative stress driven cell death," Toxicology Letters, vol. 193, no. 3, pp. 209-216, 2010.

[68] L. Lanceta, C. Li, A. M. Choi, and J. W. Eaton, "Haem oxygenase-1 overexpression alters intracellular iron distribution," Biochemical Journal, vol. 449, no. 1, pp. 189-194, 2013.

[69] K. Mukherjee, T. I. Chio, D. L. Sackett, and S. L. Bane, "Detection of oxidative stress-induced carbonylation in live mammalian cells," Free Radical Biology and Medicine, vol. 84, pp. 11-21, 2015.

[70] K. Kandasamy, S. M. Srinivasula, E. S. Alnemri et al., "Involvement of proapoptotic molecules Bax and Bak in tumor necrosis factor-related apoptosis-inducing ligand (TRAIL)-induced mitochondrial disruption and apoptosis: differential regulation of cytochrome c and Smac/DIABLO release," Cancer Research, vol. 63, no. 7, pp. 1712-1721, 2003.

[71] C. Garrido, L. Galluzzi, M. Brunet, P. E. Puig, C. Didelot, and G. Kroemer, "Mechanisms of cytochrome $c$ release from mitochondria," Cell Death \& Differentiation, vol. 13, no. 9, pp. 14231433, 2006.

[72] S.-Y. Chiou, Y.-S. Lee, M.-J. Jeng, P.-C. Tsao, and W.-J. Soong, "Moderate hypothermia attenuates oxidative stress injuries in alveolar epithelial A549 cells," Experimental Lung Research, vol. 39, no. 6, pp. 217-228, 2013.
[73] A. Mantovani, P. Allavena, A. Sica, and F. Balkwill, "Cancerrelated inflammation," Nature, vol. 454, no. 7203, pp. 436-444, 2008.

[74] L. M. Coussens and Z. Werb, "Inflammation and cancer," Nature, vol. 420, no. 6917, pp. 860-867, 2002.

[75] A. Kataki, P. Scheid, M. Piet et al., "Tumor infiltrating lymphocytes and macrophages have a potential dual role in lung cancer by supporting both host-defense and tumor progression," Journal of Laboratory and Clinical Medicine, vol. 140, no. 5, pp. 320328, 2002.

[76] A. Carus, M. Ladekarl, H. Hager, H. Pilegaard, P. S. Nielsen, and F. Donskov, "Tumor-associated neutrophils and macrophages in non-small cell lung cancer: no immediate impact on patient outcome," Lung Cancer, vol. 81, no. 1, pp. 130-137, 2013.

[77] R. A. Flavell, S. Sanjabi, S. H. Wrzesinski, and P. Licona-Limón, "The polarization of immune cells in the tumour environment by TGF $\beta$," Nature Reviews Immunology, vol. 10, no. 8, pp. 554$567,2010$.

[78] A. Bruno, C. Focaccetti, A. Pagani et al., "The proangiogenic phenotype of natural killer cells in patients with non-small cell lung cancer," Neoplasia, vol. 15, no. 2, pp. 133-142, 2013.

[79] A. L. Teixeira, A. Araújo, A. Coelho et al., "Influence of TGFB1+869T $>$ C functional polymorphism in non-small cell lung cancer (NSCLC) risk," Journal of Cancer Research and Clinical Oncology, vol. 137, no. 3, pp. 435-439, 2011.

[80] P. M. Siegel and J. Massagué, "Cytostatic and apoptotic actions of TGF- $\beta$ in homeostasis and cancer," Nature Reviews Cancer, vol. 3, no. 11, pp. 807-820, 2003.

[81] X. Luo, Q. Ding, M. Wang et al., "In vivo disruption of TGF$\beta$ signaling by Smad7 in airway epithelium alleviates allergic asthma but aggravates lung carcinogenesis in mouse," PLoS ONE, vol. 5, no. 4, Article ID e10149, 2010.

[82] M.-C. Kim, F.-J. Cui, and Y. Kim, "Hydrogen peroxide promotes epithelial to mesenchymal transition and stemness in human malignant mesothelioma cells," Asian Pacific Journal of Cancer Prevention, vol. 14, no. 6, pp. 3625-3630, 2013.

[83] C.-M. Shih, Y.-L. Lee, H.-L. Chiou et al., “The involvement of genetic polymorphism of IL-10 promoter in non-small cell lung cancer," Lung Cancer, vol. 50, no. 3, pp. 291-297, 2005.

[84] W. Dummer, J. C. Becker, A. Schwaaf, M. Leverkus, T. Moll, and E. B. Bröcker, "Elevated serum levels of interleukin-10 in patients with metastatic malignant melanoma," Melanoma Research, vol. 5, no. 1, pp. 67-68, 1995.

[85] F. De Vita, M. Orditura, G. Galizia et al., "Serum interleukin10 levels as a prognostic factor in advanced non-small cell lung cancer patients," Chest, vol. 117, no. 2, pp. 365-373, 2000.

[86] Y.-C. Wang, W.-W. Sung, T.-C. Wu et al., "Interleukin-10 haplotype may predict survival and relapse in resected non-small cell lung cancer," PLoS ONE, vol. 7, no. 7, Article ID e39525, 2012.

[87] C. Asselin-Paturel, S. Megherat, I. Vergnon et al., "Differential effect of high doses versus low doses of interleukin-12 on the adoptive transfer of human specific cytotoxic $\mathrm{T}$ lymphocyte in autologous lung tumors engrafted into severe combined immunodeficiency disease-nonobese diabetic mice: relation with interleukin-10 induction," Cancer, vol. 91, no. 1, pp. 113-122, 2001.

[88] L. M. Montuenga and R. Pio, "Tumour-associated macrophages in nonsmall cell lung cancer: the role of interleukin-10," European Respiratory Journal, vol. 30, no. 4, pp. 608-610, 2007.

[89] S. R. Pine, L. E. Mechanic, L. Enewold et al., "Increased levels of circulating interleukin 6 , interleukin 8 , C-reactive protein, and 
risk of lung cancer," Journal of the National Cancer Institute, vol. 103, no. 14, pp. 1112-1122, 2011.

[90] K.-T. Chang, C.-Y. F. Huang, C.-M. Tsai, C.-H. Chiu, and Y.-Y. Lok, "Role of IL-6 in neuroendocrine differentiation and chemosensitivity of non-small cell lung cancer," American Journal of Physiology-Lung Cellular and Molecular Physiology, vol. 289, no. 3, pp. L438-L445, 2005.

[91] A. Azevedo, V. Cunha, A. L. Teixeira, and R. Medeiros, "IL6/IL-6R as a potential key signaling pathway in prostate cancer development," World Journal of Clinical Oncology, vol. 2, no. 12, pp. 384-396, 2011.

[92] H. Yanagawa, S. Sone, Y. Takahashi et al., "Serum levels of interleukin 6 in patients with lung cancer," British Journal of Cancer, vol. 71, no. 5, pp. 1095-1098, 1995.

[93] M. Bihl, M. Tamm, M. Nauck, H. Wieland, A. P. Perruchoud, and M. Roth, "Proliferation of human non-small-cell lung cancer cell lines: role of interleukin-6," American Journal of Respiratory Cell and Molecular Biology, vol. 19, no. 4, pp. 606-612, 1998.

[94] H. Chandru and V. Boggaram, "The role of sphingosine 1phosphate in the TNF- $\alpha$ induction of IL- 8 gene expression in lung epithelial cells," Gene, vol. 391, no. 1-2, pp. 150-160, 2007.

[95] L. Gallelli, D. Falcone, M. Scaramuzzino et al., "Effects of simvastatin on cell viability and proinflammatory pathways in lung adenocarcinoma cells exposed to hydrogen peroxide," BMC Pharmacology and Toxicology, vol. 15, article 67, 2014.

[96] W. Chen, Z. Li, L. Bai, and Y. Lin, "NF-kappaB in lung cancer, a carcinogenesis mediator and a prevention and therapy target," Frontiers in Bioscience, vol. 16, no. 3, pp. 1172-1185, 2011.

[97] M. Karin, "The IkB kinase-a bridge between inflammation and cancer," Cell Research, vol. 18, no. 3, pp. 334-342, 2008.

[98] W. Wang, J.-P. Zheng, S.-X. Zhu, W.-J. Guan, M. Chen, and N.-S. Zhong, "Carbocisteine attenuates hydrogen peroxide-induced inflammatory injury in A549 cells via NF- $\kappa$ B and ERK1/2 MAPK pathways," International Immunopharmacology, vol. 24, no. 2, pp. 306-313, 2015.

[99] D. Liu, H. Guo, Y. Li, X. Xu, K. Yang, and Y. Bai, "Association between polymorphisms in the promoter regions of matrix metalloproteinases (MMPs) and risk of cancer metastasis: a meta-analysis," PLoS ONE, vol. 7, no. 2, Article ID e31251, 2012.

[100] Z. Hu, X. Huo, D. Lu et al., "Functional polymorphisms of Matrix metalloproteinase-9 are associated with risk of occurrence and metastasis of lung cancer," Clinical Cancer Research, vol. 11, no. 15, pp. 5433-5439, 2005.

[101] P. González-Arriaga, T. Pascual, A. García-Alvarez, A. Fernández-Somoano, M. F. López-Cima, and A. Tardón, "Genetic polymorphisms in MMP 2, 9 and 3 genes modify lung cancer risk and survival," BMC Cancer, vol. 12, article 121, 2012.

[102] E. I. Deryugina and J. P. Quigley, "Matrix metalloproteinases and tumor metastasis," Cancer and Metastasis Reviews, vol. 25, no. 1, pp. 9-34, 2006.

[103] C. Jumper, E. Cobos, and C. Lox, "Determination of the serum matrix metalloproteinase-9 (MMP-9) and tissue inhibitor of matrix metalloproteinase-1 (TIMP-1) in patients with either advanced small-cell lung cancer or non-small-cell lung cancer prior to treatment," Respiratory Medicine, vol. 98, no. 2, pp. 173177,2004

[104] M. Koç, D. Ediger, F. Budak et al., "Matrix metalloproteinase9 (MMP-9) elevated in serum, but not in bronchial lavage in lung cancer patients," European Respiratory Journal, vol. 42, supplement 57, Article ID P2898, 2013.
[105] D. Liu, J. Nakano, S. Ishikawa et al., "Overexpression of matrix metalloproteinase-7 (MMP-7) correlates with tumor proliferation, and a poor prognosis in non-small cell lung cancer," Lung Cancer, vol. 58, no. 3, pp. 384-391, 2007.

[106] J. J. Atkinson and R. M. Senior, "Matrix metalloproteinase-9 in lung remodeling," American Journal of Respiratory Cell and Molecular Biology, vol. 28, no. 1, pp. 12-24, 2003.

[107] S. Zucker, R. M. Lysik, M. Malik, B. A. Bauer, J. Caamano, and A. J. P. Klein-Szanto, "Secretion of gelatinases and tissue inhibitors of metalloproteinases by human lung cancer cell lines and revertant cell lines: not an invariant correlation with metastasis," International Journal of Cancer, vol. 52, no. 3, pp. 366-371, 1992.

[108] R. R. Baruch, H. Melinscak, J. Lo, Y. Liu, O. Yeung, and R. A. R. Hurta, "Altered matrix metalloproteinase expression associated with oncogene-mediated cellular transformation and metastasis formation," Cell Biology International, vol. 25, no. 5, pp. 411-420, 2001.

[109] J. Phuchareon, F. McCormick, D. W. Eisele, and O. Tetsu, "EGFR inhibition evokes innate drug resistance in lung cancer cells by preventing Akt activity and thus inactivating Ets-1 function," Proceedings of the National Academy of Sciences of the United States of America, vol. 112, no. 29, pp. E3855-E3863, 2015.

[110] H.-C. Huang, S.-Y. Liu, Y. Liang, Y. Liu, J.-Z. Li, and H.-Y. Wang, "Transforming growth factor- $\beta 1$ stimulates matrix metalloproteinase-9 production through ERK activation pathway and upregulation of Ets-1 protein," Zhonghua Yi Xue Za Zhi, vol. 85, no. 5, pp. 328-331, 2005.

[111] L. A. Wilson, A. Gemin, R. Espiritu, and G. Singh, "ets-1 is transcriptionally up-regulated by $\mathrm{H}_{2} \mathrm{O}_{2}$ via an antioxidant response element," The FASEB Journal, vol. 19, no. 14, pp. 2085-2087, 2005.

[112] Z.-R. Shao, Q. Wang, X.-F. Xu et al., "Phospholipase D participates in $\mathrm{H}_{2} \mathrm{O}_{2}$-induced A549 alveolar epithelial cell migration," Experimental Lung Research, vol. 38, no. 8, pp. 427-433, 2012.

[113] A. Yemm, D. Adams, and N. Kalia, "Targeting the delivery of systemically administered haematopoietic stem/progenitor cells to the inflamed colon using hydrogen peroxide and platelet microparticle pre-treatment strategies," Stem Cell Research, vol. 15, no. 3, pp. 569-580, 2015.

[114] D. Trachootham, J. Alexandre, and P. Huang, "Targeting cancer cells by ROS-mediated mechanisms: a radical therapeutic approach?" Nature Reviews Drug Discovery, vol. 8, no. 7, pp. 579-591, 2009.

[115] M. López-Lázaro, "Dual role of hydrogen peroxide in cancer: possible relevance to cancer chemoprevention and therapy," Cancer Letters, vol. 252, no. 1, pp. 1-8, 2007.

[116] R. Kachadourian, H. M. Brechbuhl, L. Ruiz-Azuara, I. GraciaMora, and B. J. Day, "Casiopeína IIgly-induced oxidative stress and mitochondrial dysfunction in human lung cancer A549 and H157 cells," Toxicology, vol. 268, no. 3, pp. 176-183, 2010.

[117] M. López-Lázaro, "A new view of carcinogenesis and an alternative approach to cancer therapy," Molecular Medicine, vol. 16, no. 3-4, pp. 144-153, 2010.

[118] E. Panieri, V. Gogvadze, E. Norberg, R. Venkatesh, S. Orrenius, and B. Zhivotovsky, "Reactive oxygen species generated in different compartments induce cell death, survival, or senescence," Free Radical Biology and Medicine, vol. 57, pp. 176-187, 2013.

[119] S. Saha, M. Ghosh, and S. K. Dutta, "A potent tumoricidal co-drug 'Bet-CA'-an ester derivative of betulinic acid and dichloroacetate selectively and synergistically kills cancer cells," Scientific Reports, vol. 5, article 7762, 2015. 
[120] O. Volotskova, T. S. Hawley, M. A. Stepp, and M. Keidar, "Targeting the cancer cell cycle by cold atmospheric plasma," Scientific Reports, vol. 2, article 636, 2012.

[121] H. J. Ahn, K. I. Kim, N. N. Hoan et al., “Targeting cancer cells with reactive oxygen and nitrogen species generated by atmospheric-pressure air plasma," PLoS ONE, vol. 9, no. 1, Article ID e86173, 2014.

[122] M. Keidar, R. Walk, A. Shashurin et al., "Cold plasma selectivity and the possibility of a paradigm shift in cancer therapy," British Journal of Cancer, vol. 105, no. 9, pp. 1295-1301, 2011.

[123] M. Vandamme, E. Robert, S. Lerondel et al., "ROS implication in a new antitumor strategy based on non-thermal plasma," International Journal of Cancer, vol. 130, no. 9, pp. 2185-2194, 2012.

[124] H. Lee, S. Kang, W. Kim, and E. Hernandez-Lemus, "Drug repositioning for cancer therapy based on large-scale drug-induced transcriptional signatures," PLoS ONE, vol. 11, no. 3, Article ID e0150460, 2016. 


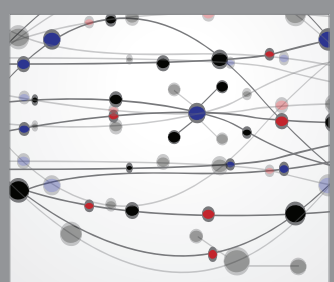

The Scientific World Journal
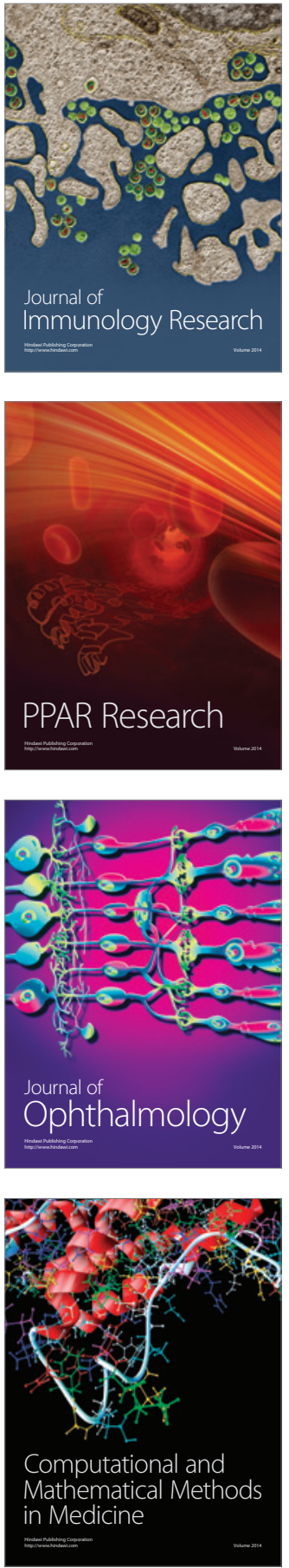

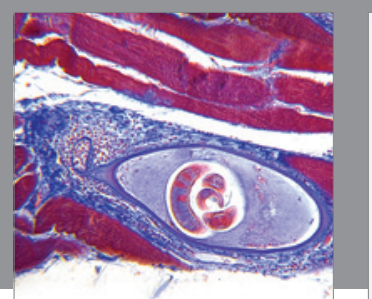

Gastroenterology Research and Practice

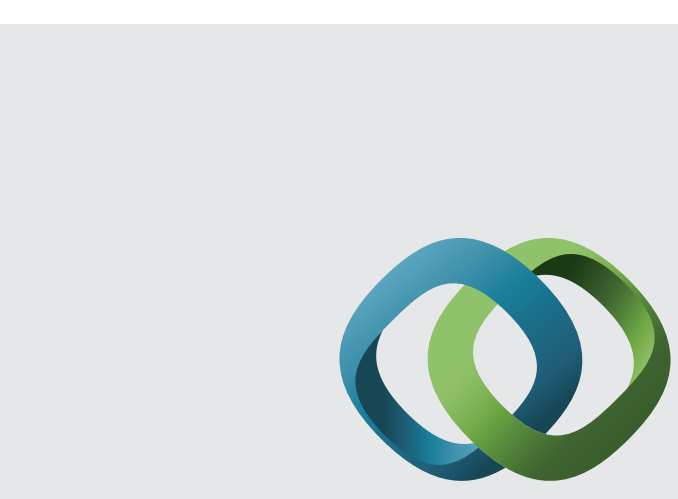

\section{Hindawi}

Submit your manuscripts at

http://www.hindawi.com
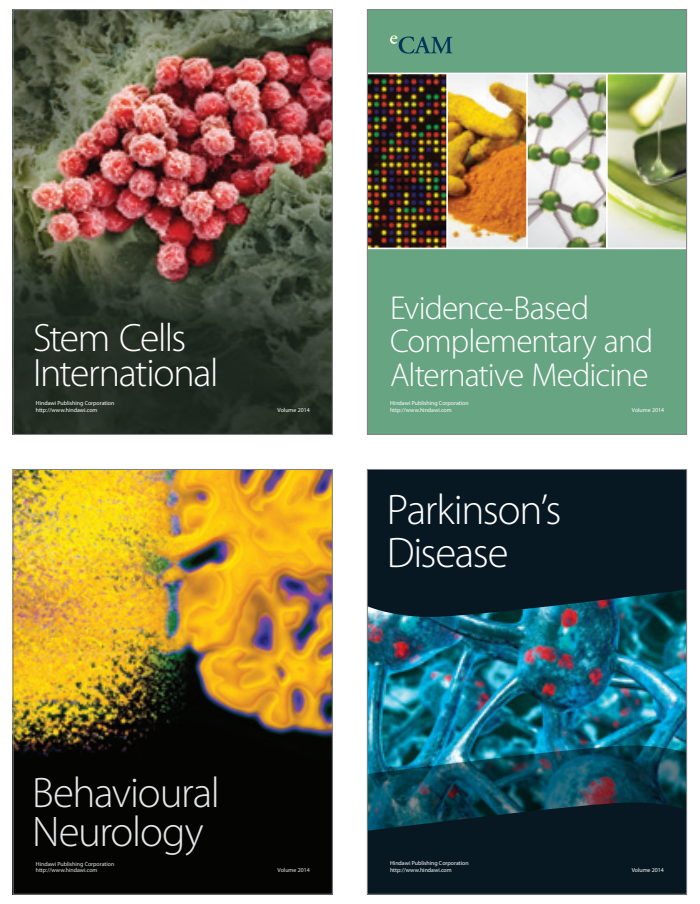
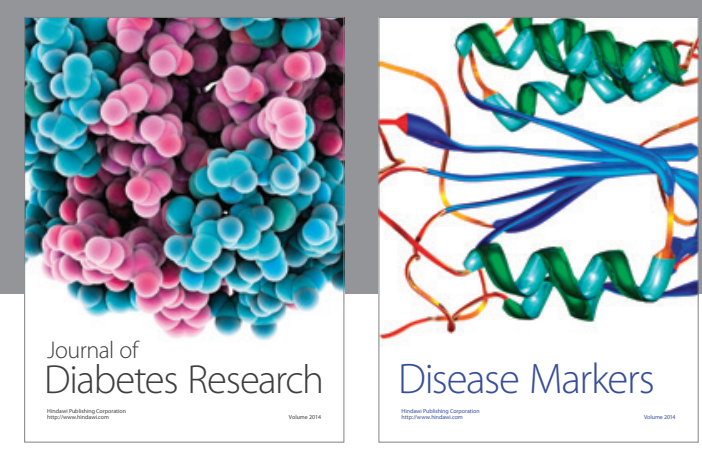

Disease Markers
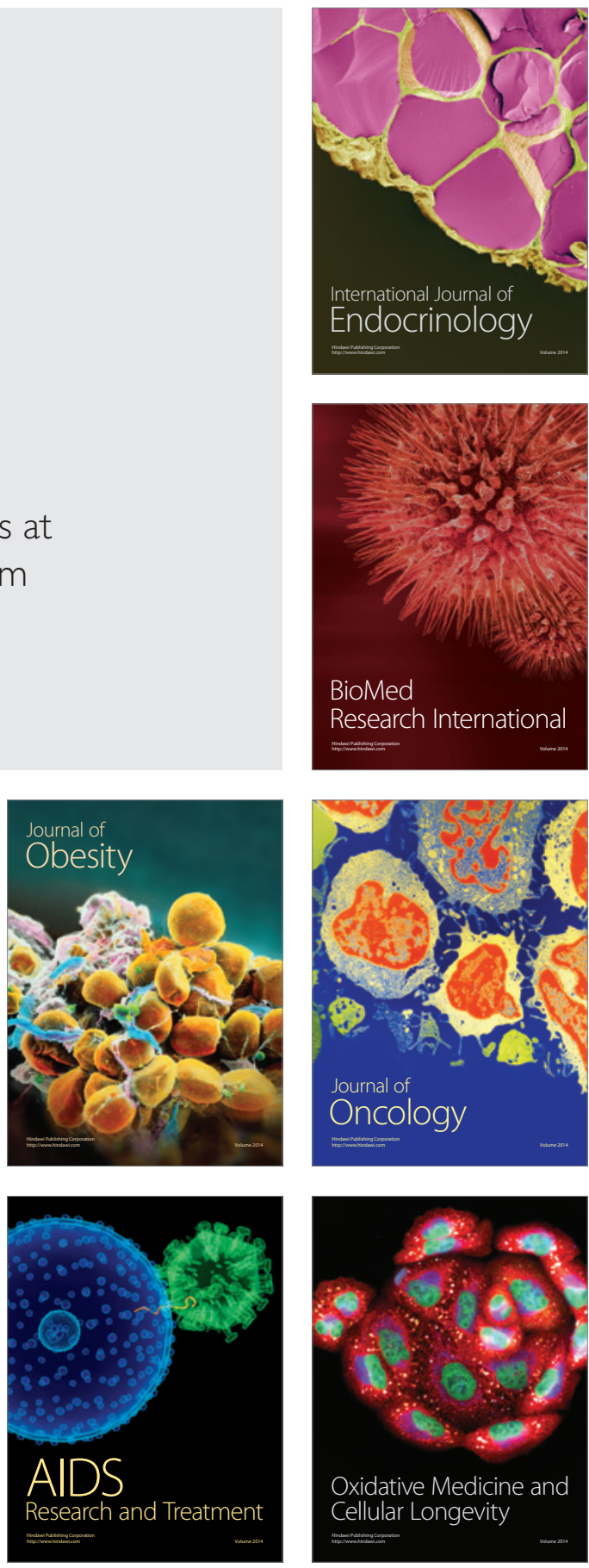